\title{
A PVP-extract fungal protein of Omphalia lapideacens and its antitumor activity on human gastric tumors and normal cells
}

\author{
YI-TAO CHEN ${ }^{1}$, QUN-YING LU ${ }^{2}$, MEI-AI LIN ${ }^{1}$, DONG-QING CHENG ${ }^{1}$, ZHI-SHAN DING $^{1 *}$ and LE-TIAN SHAN ${ }^{{ }^{*}}$ \\ ${ }^{1}$ Zhejiang Chinese Medical University, Hangzhou; ${ }^{2}$ Zhejiang Provincial Center for \\ Disease Control and Prevention, Hangzhou 310053, P.R. China
}

Received June 9, 2011; Accepted August 8, 2011

DOI: $10.3892 /$ or.2011.1448

\begin{abstract}
Omphalia lapidescens is an important medicinal fungus as well as traditional Chinese medicine used for disease treatment. It is mainly used as a vermifuge for anthelmintic therapy, but it has not been hitherto reported to possess antitumor activity. In this study, a purified bioactive protein in $O$. lapidescens $(\mathrm{pPeOp}$ ) was obtained using polyvinylpyrrolidone (PVP) followed by gel filtration chromatography. To evaluate the in vitro antitumor activity of $\mathrm{pPeOp}$ in human gastric tumor cells (MC-4 and SGC-7901) and normal cells (MC-1), MTT assay and FCM assay were used and the morphological changes, cell viability, cell death rate and cell apoptosis rate of MC-4, SGC-7901 and MC-1 cells were estimated. The results showed that $\mathrm{pPeOp}$ could significantly reduce the cell viability of MC-4 and SGC-7901 cells in a concentration-dependent manner, with $\mathrm{IC}_{50}$ values of 236.05 and $156.28 \mu \mathrm{g} / \mathrm{ml}$, respectively. The morphological observation also indicated a similar result. In FCM assays, a significant increase of cell death rate and cell apoptosis rate of the tumor cells were observed, indicating probable necrosisinducing effects and/or apoptosis-inducing effects of $\mathrm{pPeOp}$. Importantly, there was no significant effect of $\mathrm{pPe} O \mathrm{p}$ on $\mathrm{MC}-1$ cells in each assay, showing that $\mathrm{pPe} O \mathrm{p}$ has no adverse effects on the normal cells. In conclusion, $\mathrm{pPe} O \mathrm{p}$ is a newly discovered bioactive protein in $O$. lapidescens and this is the first report on antitumor activity of such a fungal protein. This may provide a meaningful basis for developing a new protein drug for treatment against cancer, especially gastric cancer.
\end{abstract}

\section{Introduction}

Cancer is a malignant disease induced by disorganized cell cycle and uncontrolable tumor cell growth, which has become

Correspondence to: Dr Le-Tian Shan, Institute of Orthopaedics and Traumatology, Zhejiang Chinese Medical University, No. 548 Binwen Road, Binjiang District, Hangzhou 310053, P.R. China E-mail: letian.shan@hotmail.com

*Contributed equally

Key words: Omphalia lapidescens, polyvinylpyrrolidone, antitumor, gastric cancer, human gastric tumor, MTT, flow cytometry a major public health problem for the whole world. The tumor cells form a mass of tissues which proliferate rapidly, spread throughout the body and may eventually cause death of the host (1). The main strategies for treating cancer are surgery and radiation, even if these are rarely successful unless the tumor is diagnosed at an early stage. For advanced tumors, chemotherapy is the primary choice of treatment. However, this is not an ideal choice since the chemical drugs used are associated with severe adverse events and drug resistance (2). This prompted us to seek for new therapeutic options with better efficacy and less side effect for tumor treatment. Recently, medicinal fungi have attracted much attention and generated great interest for its potential applications in the cancer therapy field (3-6). This kind of natural products are promising candidates which display little toxicity and low side effect, suggesting their certain advantage over the chemotherapeutic agents (7).

Omphalia lapidescens Schroeter (Lei-wan in Chinese), a member of traditional Chinese medicines (TCM), is one of the most important medicinal fungi in China and has been widely used for long time in clinical practices of anthelmintic therapy. It is well known as a vermifuge, possessing medicinal activity against many kinds of parasites such as roundworms, cestodes and ancylostomes $(8,9)$. This fungus was originally reported in Shennong Materia Medica, the earliest Pharmacopoeia of China in Eastern Han Dynasty (24-220 AD), and was recently described in the Chinese Pharmacopoeia (2010 edition) (10). According to the Pharmacopoeia description, O. lapidescens is attributed to the stomach and large intestine meridians, indicating its potential effects in these two organs (11). Modern pharmacological studies have demonstrated that a $O$. lapidescens protein (neutral metalloprotease) can exert anthelmintic activity whilst its polysaccharide (a fungal $(1 \rightarrow 3)-\beta$-D-glucan) possesses limited antitumor activity against murine solid and ascites tumors $(12,13)$. However, no report of any antitumor protein of $O$. lapidescens has been published, except our preliminary one in which a crude antitumor protein extract was found (14).

Polyvinylpyrrolidone (PVP) is a multifunctional macromolecular product developed by Reppe $(15,16)$ in his study of acetylene chemistry. This water-soluble high polymer possesses many interesting properties such as non-toxicity, high solubility, chemical stability, and physiological compatibility (17). It was initially utilized as a plasma extender and 
a carrier or vehicle for various substances in the blood stream (18). Recently, it has been found to possess protective effect on enzymes and proteins against polyphenol-induced denaturation, via its high affinity to polyphenols (19). This activity has resulted in a positive application of PVP in the extraction of active proteins or enzymes from the plants $(20,21)$.

In the present study, a PVP-extracted protein of $O$. lapidescens was purified and characterized. Its in vitro antitumor activity was also evaluated by assessing cytotoxicity against two human gastric carcinoma cell lines (MC-4 and SGC-7901), using MTT cell viability assay and flow cytometry (FCM) assay.

\section{Materials and methods}

Materials and reagents. The fruiting body of $O$. lapidescens was purchased from Fang Hui Chun Tang Traditional Chinese Medicine Drugstore (Hangzhou, China) and authenticated by the authors for protein extraction. Fetal bovine serum (FBS) was provided by Hangzhou Sijiqing Biological Engineering Material Company (Hangzhou). Trypsin, Dulbecco's modified Eagle's medium (DMEM) and RPMI-1640 medium were purchased from Gibco Invirogen Corp. (Paisley, UK). Hoechst 33258 Kit was obtained from Jiangsu Beyotime Institute of Biological Technique (Nantong, China). Annexin V-FITC Apoptosis Detection Kit I was purchased from BD Pharmingen (San Diego, USA). BCA Protein Assay Reagent Kit was provided by Nanjing KeyGen Biotechnology Company (Nanjing, China). 3-(4,5-Dimethylthiazol-2-yl)-2,5diphenyltetrazolium bromide (MTT) and dimethyl sulfoxide (DMSO) were purchased from Sigma Chemical Co. (St. Louis, CA, USA). PVP (K30) was obtained from Shanghai Bio Life Science and Technology Co. (Shanghai, China). Other reagents and solvents were of analytical grade and commercially available.

Protein extraction and purification. A mass of $O$. lapidescens fruiting body (200 mg) was washed with $4^{\circ} \mathrm{C}$ distilled water three times, followed by freeze-drying. It was then ground in liquid nitrogen to fine powders and placed into $0.875 \mathrm{ml}$ iced PVP-extraction buffer (15\% 1.0 M Tris-HCl, $\mathrm{pH}$ 8.0; $2 \%$ PVP; $25 \%$ glycerol) for $4 \mathrm{~h}$. After centrifugation (12000 x g, $20 \mathrm{~min}$ ) at $4^{\circ} \mathrm{C}$, the supernatant was collected and kept for the next step.

Gel filtration chromatography was employed to purify proteins from the above extract. The supernatant was loaded onto a Sephadex G-50 column (Pharmacia Biotechnology, Uppsala, Sweden) which was pre-equilibrated with $50 \mathrm{mM}$ Tris- $\mathrm{HCl}$ buffer ( $\mathrm{pH} 8.5)$. The flow rate was $0.2 \mathrm{ml} / \mathrm{min}$, and the absorbance was monitored at $280 \mathrm{~nm}$. There were three $\mathrm{A}_{280 \mathrm{~nm}}$ peak fractions, named G-1, G-2 and G-3, of which G-2 was ultrafiltrated by Millipore ultrafiltration tube (cut-off of $3 \mathrm{kDa}$ ) at $4000 \mathrm{rpm}$ for $30 \mathrm{~min}$ and prepared as a purified PVP-extracted $O$. lapideacens protein ( $\mathrm{pPe} O \mathrm{p}$ ) for further analysis.

Protein assay and tricine-SDS-PAGE. Overall protein contents of the crude $O$. lapideacens extract and $\mathrm{pPe} O \mathrm{p}$ were determined by the standard BCA protein assay (22). Possible components in the extract before and after purification were analyzed by tricine-SDS-PAGE (23) using Hoefer miniVE vertical electrophoresis system (Amersham Pharmacia Biotech, Uppsala, Sweden). Briefly, $10 \mu 1$ aliquots of the sample $(1 \mathrm{mg} / \mathrm{ml})$ were loaded on tricine-SDS gels (4\% stacking gel and $16 \%$ resolving gel). The stacking gel was run at $10 \mathrm{~mA}$ and the resolving at $20 \mathrm{~mA}$. After electrophoresis, protein band was detected by Coomassie brilliant blue staining method (24). Conspicuous protein component present in $\mathrm{pPeOp}$ was selected as a target for further study.

Tumor cell lines and culture condition. Human normal gastric epithelial (MC-1) cells and carcinoma (MC-4 and SGC-7901) cells were provided by Zhejiang Provincial Center for Disease Control and Prevention (Zhejiang CDC) (Hangzhou, China). The MC- 1 and MC- 4 cells were cultured in DMEM containing $10 \%$ fetal calf serum (FCS), $20 \mathrm{mM} \mathrm{L-glutamine,} 100 \mathrm{U} / \mathrm{ml}$ penicillin, and $100 \mu \mathrm{g} / \mathrm{ml}$ streptomycin, while the SGC-7901 cells were incubated in RPMI-1640 medium supplemented with $100 \mathrm{ml} / 1 \mathrm{FCS}, 20 \mathrm{mM}$ L-glutamine, $100 \mathrm{U} / \mathrm{ml}$ penicillin, and $100 \mu \mathrm{g} / \mathrm{ml}$ streptomycin. All cell lines were maintained in a humidified incubator at $37^{\circ} \mathrm{C}$ and $5 \% \mathrm{CO}_{2}$ atmosphere.

Antitumor activity of pPeOp in vitro. Cultured cells (MC-1, MC-4 and SGC-7901) taken in the stage of logarithmic growth were detached with $0.25 \%$ trypsin and cell suspensions were made in a medium described above. Their cell viabilities were shown to be in excess of $98 \%$ by trypan blue exclusion test. Aliquots of the suspension of each cell strain containing $5 \times 10^{4}$ cells were seeded in each well of two culture plates (96-well plate for MTT assay and 12-well plate for FCM assay) and incubated at $37^{\circ} \mathrm{C}$ under $5 \% \mathrm{CO}_{2}$ for $24 \mathrm{~h}$. Then DMEMdiluted (for MC-1 and MC-4) and RPMI-1640-diluted (for SGC-7901) pPe $O$ p suspenstions $(120,90,60,45$ and $30 \mu \mathrm{g} / \mathrm{ml})$, which has been sterilized by filtration using $0.22 \mu \mathrm{m}$ Millipore filter, were separately used to treat the cells in each well for each cell strain. The PVP $(120 \mu \mathrm{g} / \mathrm{ml})$ treated cells was used as the negative control and untreated cells as normal control. After the treatment, cells in each plate were incubated for $18 \mathrm{~h}$ at $37^{\circ} \mathrm{C}$ with $5 \% \mathrm{CO}_{2}$, awaiting the following tests.

Morphological analysis. The cytotoxicity of pPeOp against human gastric carcinoma cells was evaluated from a morphological perspective. A light microscope was adopted to observe the $\mathrm{pPe} O \mathrm{p}$-induced cell damage. The incubated cells were stained with Hoechst 33258 using apoptotic nuclear chromatin staining kit, followed by PBS washes for three times. The cells were examined and photographed by Leica DMIRE2 inverted fluorescence microscope system (Leica Microsystems Corp., Bensheim, Germany).

MTT assay. The MTT assay was employed to further evaluate the $\mathrm{pPe} O \mathrm{p}$ cytotoxicity on the tumor cells. After the last incubation, $10 \mu \mathrm{l}$ of MTT solution $(5 \mathrm{mg} / \mathrm{ml})$ was added to each well of the 96-well plate and the plate was incubated at $37^{\circ} \mathrm{C}$ for $4 \mathrm{~h}$. The supernatant was carefully removed and to each well $150 \mu$ l DMSO was added. The plate was gently shaken for $10 \mathrm{~min}$ and the optical density (OD) at $490 \mathrm{~nm}$ of each well was determined by a microplate reader (Wellscan MK3; Thermo labsystems, Helsinki, Finland). The cytotoxic activity of $\mathrm{pPe} O \mathrm{p}$ is expressed as $\mathrm{IC}_{50}$ (i.e., the concentration inhibiting cell proliferation by $50 \%$ compared with the untreated 
control). The cell viability of the treated groups was expressed as a percentage of normal control groups, which was assumed to be $100 \%$. Three experimental replicates were carried out for each sample.

FCM assay. The pPeOp cytotoxicity was also evaluated by FCM assay. After the last incubation, cells in the 12-well plate were collected and rinsed twice with phosphate-buffered saline (PBS), and then were suspended in the binding buffer to reach a concentration of $1 \times 10^{6}$ cells per ml. Each suspension $(100 \mu \mathrm{l})$ was stained with $5 \mu$ l FITC-labeled Annexin V and $5 \mu 1$ propidium iodide (PI) using Annexin V-FITC Apoptosis Detection Kit I as instructed by the manufacturer. A FCM analysis was carried out to detect fluorescent cells using Beckman Coulter Epics Altra flow cytometer (Beckman Coulter Corp., CA, USA) for assessing cytotoxicity of $\mathrm{pPe} O \mathrm{p}$. Three experimental replicates were performed for each sample.

Statistical analysis. All measurements were expressed as the mean \pm standard deviation and subjected to one-way analysis of variance (ANOVA), followed by Fisher's least significant difference (LSD) comparison. P-value of $<0.05$ was considered statistically significant and $\mathrm{P}<0.01$ very significant. All analyses were performed using an updated version of DPS software (25).

\section{Results}

Isolation and purification of $O$. lapidescens proteins. The PVP extracted protein components of O. lapidescens were distinguished and presented on the tricine-SDS-PAGE profile, the major bands of which were seen below $20 \mathrm{kDa}$ (Fig. 1, lane 1). After purification by molecular-sieve chromatography, the extracted proteins were separated into three fractions (G-1, G-2 and G-3) through Tris-HCl elution on Sephadex G-50 column (Fig. 2). Of the three, the highest peak of protein fractions was found in G-2, indicating that it might be the first major fraction with a highest protein concentration. A tricine-SDS-PAGE analysis of G-2 was carried out and the result showed that only one protein band (about $16 \mathrm{kDa}$ ) was retained after the purification (Fig. 1, lane 2). This protein was defined as $\mathrm{pPe} O \mathrm{p}$.

Morphological changes induced by pPeOp. A light microscopy was applied to analyze the morphological changes of the normal cells (MC-1) and tumor cells (MC-4 and SGC-7901) as well as their cell nuclei. As shown in Fig. 3A and C, untreated MC-1 and MC-4 in the normal control displayed normal cell shape and natural cell apoptosis, indicating the normal condition of these cells. When treated with the PVP buffer, MC-4 still remained normal as compared to its normal control (Fig. 3D), showing that PVP had no effect on the tumor cells. However, after exposure to a concentration gradient of $\mathrm{pPeOp}(30,45$, 60, 90 and $120 \mu \mathrm{g} / \mathrm{ml}), \mathrm{MC}-4$ was significantly damaged by cell shrinkage, membrane blebbing, boundary split or aggregation, and underwent an increasing cell death with increasing $\mathrm{pPe} O \mathrm{p}$ concentrations (Fig. 3E-I). In contrast, with the highest level of $\mathrm{pPe} O \mathrm{p}(120 \mu \mathrm{g} / \mathrm{ml})$, no significant cell death was seen in MC-1 compared to its normal control (Fig. 3B), indicating that $\mathrm{pPe} O \mathrm{p}$ at that level had no cytotox-

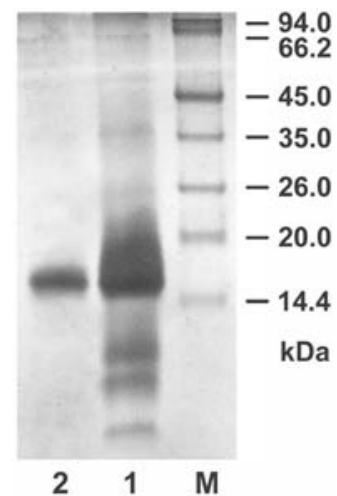

Figure 1. The tricine-SDS-PAGE of protein extracts of $O$. lapideacens before and after purification. M, molecular mass protein markers; lane 1, unpurified protein extract; lane $2, \mathrm{pPe} O \mathrm{p}$.

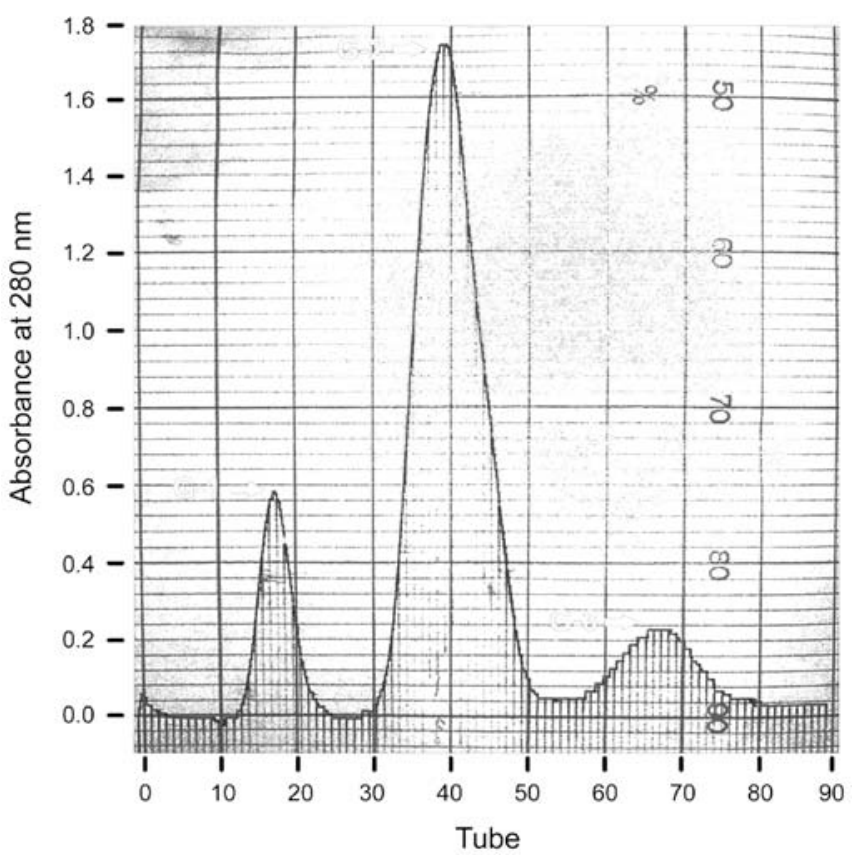

Figure 2. The curve of $O$. lapideacens proteins separated by Sephadex G-50 chromatography. Column specification, $10 \times 600 \mathrm{~mm}$; equilibrate liquid,

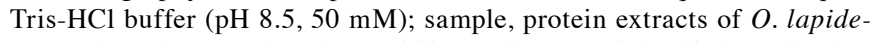
acens; detection wavelength, UV $280 \mathrm{~nm}$; flow rate, $0.2 \mathrm{ml} / \mathrm{min}$; collection rate, $1 \mathrm{ml} /$ tube.

icity on the normal gastric cells. The morphological changes of SGC-7901 displayed a similar pattern to MC-4 (data not shown).

Under a fluorescence microscopy, morphological changes of cells and cell nuclei were further observed after Hoechst 33258 staining. In the normal control group, MC-1 and MC-4 were normally round in shape and homogeneously stained, with uniform chromatin across the nuclei (Fig. 4A and C). A similar morphological profile was found in the PVP-treated MC-4 group (Fig. 4D). However, after the same treatments on $\mathrm{MC}-4$ with $\mathrm{pPe} O \mathrm{p}$ concentration gradient as indicated above, typical morphological changes such as cell shrinkage or collapse, boundary split or aggregation, nuclei condensation, and nucleus fragmentation were observed to intensify along 

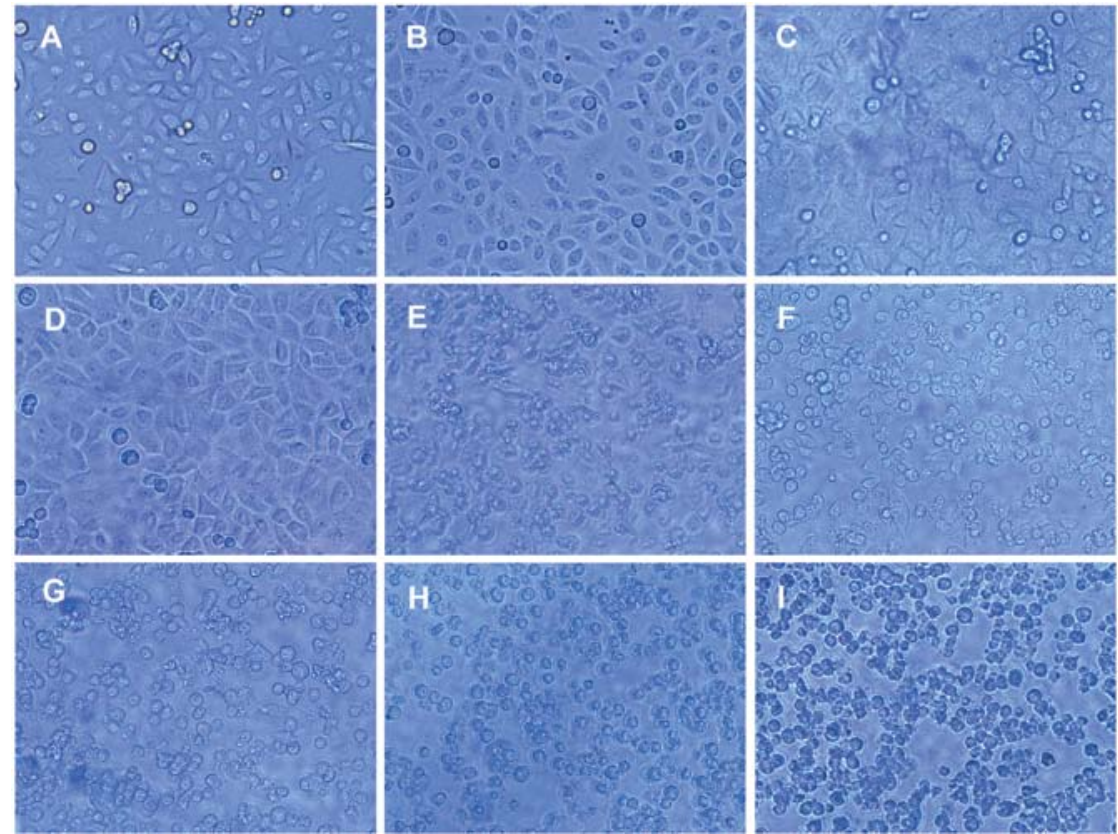

Figure 3. Morphological views of the cultured tumor cells (MC-4) and normal cells (MC-1) with concentration-gradient treatment of pPe $O \mathrm{p}$ (x200). (A) Normal control of MC-1 cells; (B) MC-1 cells treated with $120 \mu \mathrm{g} / \mathrm{ml} \mathrm{pPe} O \mathrm{p}$; (C) normal control of MC-4 cells; (D) PVP treated MC-4 cells; (E-I) MC-4 cells treated with $\mathrm{pPe} O \mathrm{p}$ of gradient concentrations $(30,45,60,90$ and $120 \mu \mathrm{g} / \mathrm{ml})$.
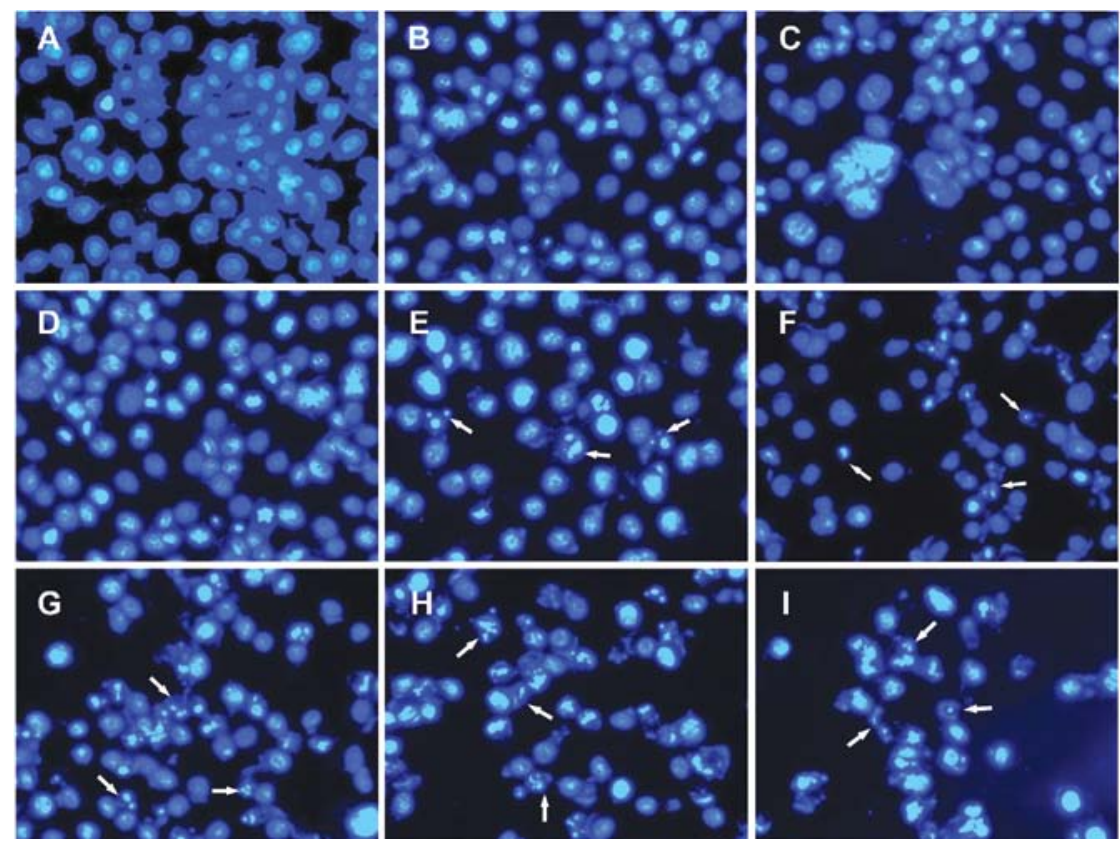

Figure 4. Morphological analysis of Hoechst 33258 stained tumor cells (MC-4) and normal cells (MC-1) with concentration-gradient treatment of pPeOp (x200). (A) Normal control of MC-1 cells; (B) MC-1 cells treated with $120 \mu \mathrm{g} / \mathrm{ml} \mathrm{pPe} O \mathrm{p}$; (C) normal control of MC-4 cells; (D) PVP treated MC-4 cells; (E-I) MC-4 cells treated with $\mathrm{pPe} O \mathrm{p}$ of gradient concentrations $(30,45,60,90$ and $120 \mu \mathrm{g} / \mathrm{ml})$.

with the increasing pPeOp concentrations (Fig. 4E-I). But contrarily, $\mathrm{pPe} O \mathrm{p}$ at the highest concentration failed to cause any significant morphological change of MC-1 when compared to its normal control (Fig. 4B). These results, together with the similar findings from the light microscopy, suggested that $\mathrm{pPe} O \mathrm{p}$ itself could induce apoptosis-like cell death only of the $\mathrm{MC}-4$ rather than $\mathrm{MC}-1$, thereby indicating that $\mathrm{pPeO}$ p might have the capability of inhibiting gastric tumor cells with no effect on normal gastric cells.
Cytotoxicity of pPeOp tested by MTT assay. Given the cytotoxicity of $\mathrm{pPe} O \mathrm{p}$ derived from the morphological analysis, dose-dependent MTT assay was performed to measure the cell proliferation inhibition activity of $\mathrm{pPe} O \mathrm{p}$ which was expressed by cell viability and the $\mathrm{IC}_{50}$. As illustrated in Fig. 5, when compared with the normal controls, the decrease of cell viability in MC-4 and SGC-7901 became more significant with increasing concentration of $\mathrm{pPe} O \mathrm{p}(\mathrm{P}<0.05$ and $\mathrm{P}<0.01)$ and no more than $70 \%$ cell viability were seen in their $120 \mu \mathrm{g} /$ 


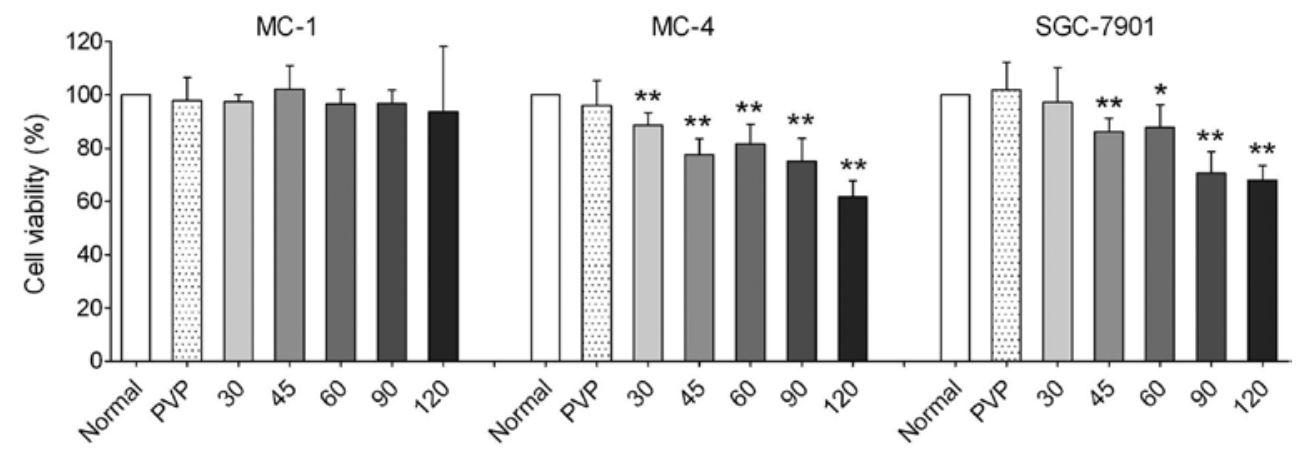

Figure 5. Cytotoxicity of pPeOp on the viability of normal cells (MC-1) and tumor cells (MC-4 and SGC-7901) determined by MTT assays. Results are presented as a percentage of control group viability. Values are the mean \pm SD. ${ }^{*} \mathrm{P}<0.05$ and ${ }^{* * *} \mathrm{P}<0.01$ vs. normal control group.

Table I. Assessment of pPeOp-inducing cell death or apoptosis of normal cells (MC-1) and tumor cells (MC-4 and SGC-7901) by FCM assay.

\begin{tabular}{|c|c|c|c|c|c|c|}
\hline \multirow[b]{2}{*}{ Groups } & \multicolumn{2}{|c|}{ MC-1 } & \multicolumn{2}{|c|}{ MC-4 } & \multicolumn{2}{|c|}{ SGC-7901 } \\
\hline & Death (\%) & Apoptosis (\%) & Death (\%) & Apoptosis (\%) & Death $(\%)$ & Apoptosis (\%) \\
\hline Normal & $1.4 \pm 0.92$ & $1.2 \pm 0.76$ & $1.8 \pm 1.15^{\mathrm{c}}$ & $4.3 \pm 2.83^{\mathrm{b}}$ & $4.3 \pm 2.26^{\mathrm{b}}$ & $3.8 \pm 1.34^{\mathrm{b}}$ \\
\hline PVP & $1.6 \pm 1.41$ & $1.1 \pm 0.44$ & $2.1 \pm 0.58^{c}$ & $3.1 \pm 1.76^{\mathrm{b}}$ & $4.2 \pm 0.53^{\mathrm{b}}$ & $2.6 \pm 0.88^{\mathrm{b}}$ \\
\hline $30 \mu \mathrm{g} / \mathrm{ml} \mathrm{pPe} O \mathrm{p}$ & $1.5 \pm 0.96$ & $4.4 \pm 1.07$ & $1.9 \pm 0.48^{\mathrm{c}}$ & $9.5 \pm 6.35^{\mathrm{a}, \mathrm{b}}$ & $24.3 \pm 7.93^{\mathrm{a}}$ & $8.6 \pm 3.80^{\mathrm{b}}$ \\
\hline $45 \mu \mathrm{g} / \mathrm{ml} \mathrm{pPe} O \mathrm{p}$ & $1.3 \pm 0.15$ & $5.2 \pm 1.59$ & $3.5 \pm 2.45^{\mathrm{b}, \mathrm{c}}$ & $17.2 \pm 1.25^{\mathrm{a}}$ & $17.0 \pm 9.93^{\mathrm{a}, \mathrm{b}}$ & $11.7 \pm 7.84^{\mathrm{b}}$ \\
\hline $60 \mu \mathrm{g} / \mathrm{ml} \mathrm{pPe} O \mathrm{p}$ & $1.8 \pm 0.92$ & $5.8 \pm 2.06$ & $8.1 \pm 1.97^{\mathrm{a}, \mathrm{b}, \mathrm{c}}$ & $14.6 \pm 8.50^{\mathrm{a}}$ & $18.2 \pm 8.35^{\mathrm{a}, \mathrm{b}}$ & $18.0 \pm 13.00^{\mathrm{a}, \mathrm{b}}$ \\
\hline $90 \mu \mathrm{g} / \mathrm{ml} \mathrm{pPe} O \mathrm{p}$ & $1.7 \pm 1.10$ & $5.5 \pm 4.72$ & $12.0 \pm 7.18^{\mathrm{a}, \mathrm{b}}$ & $18.4 \pm 10.03^{\mathrm{a}}$ & $26.6 \pm 17.84^{\mathrm{a}}$ & $13.9 \pm 9.43^{\mathrm{b}}$ \\
\hline $120 \mu \mathrm{g} / \mathrm{ml} \mathrm{pPe} O \mathrm{p}$ & $2.6 \pm 2.49$ & $5.3 \pm 1.27$ & $17.3 \pm 11.44^{\mathrm{a}}$ & $9.2 \pm 2.19^{\mathrm{a}, \mathrm{b}}$ & $17.3 \pm 3.55^{\mathrm{a}, \mathrm{b}}$ & $35.2 \pm 20.02^{\mathrm{a}}$ \\
\hline F-test & - & - & 3.99 & 3.31 & 2.86 & 2.96 \\
\hline LSD test & $P>0.05$ & $P>0.05$ & $\mathrm{P}<0.05$ & $\mathrm{P}<0.05$ & $\mathrm{P}<0.05$ & $\mathrm{P}<0.05$ \\
\hline
\end{tabular}

Values are the mean \pm SD. Table entries with different lowercase letters in each column differ significantly $(L S D, P<0.05)$.

$\mathrm{ml} \mathrm{pPe} O \mathrm{p}$ treated cultures $(61.67 \%$ in $\mathrm{MC}-4$ and $68.10 \%$ in SGC-7901), while none of the $\mathrm{pPe} O \mathrm{p}$ concentrations had significant effect on the cell viability of MC-1 (all P>0.05). Moreover, PVP at a high concentration $(120 \mu \mathrm{g} / \mathrm{ml})$ failed to cause any significant reduction of cell viability in each cell line under the same experimental condition (all $\mathrm{P}>0.05$ ). In $\mathrm{MC}-4, \mathrm{pPe} O \mathrm{p}$ exerted significant inhibitory effect on the cell viability over its whole concentration range from 30 to $120 \mu \mathrm{g} / \mathrm{ml}$ (all $\mathrm{P}<0.01$ ) with $\mathrm{IC}_{50}$ value of $236.05 \mu \mathrm{g} / \mathrm{ml}$. In SGC-7901, the cell viability was significantly inhibited by $\mathrm{pPe} O \mathrm{p}$ over a range from 45 to $120 \mu \mathrm{g} / \mathrm{ml}(\mathrm{P}<0.01$ for 45 , 90 and $120 \mu \mathrm{g} / \mathrm{ml} ; \mathrm{P}<0.05$ for $60 \mu \mathrm{g} / \mathrm{ml})$, with $\mathrm{IC}_{50}$ value of $156.28 \mu \mathrm{g} / \mathrm{ml}$.

Cytotoxicity of pPeOp tested by FCM assay. FCM assay was employed using Annexin V-FITC and PI double staining to further evaluate the cytotoxicity of $\mathrm{pPe} O \mathrm{p}$ on normal gastric cells (MC-1) and gastric tumor cells (MC-4 and SGC-7901). Complete cell death of each group was represented by the upper left quadrant of the cell plot (FITC Annexin $\mathrm{V}^{-} / \mathrm{PI}^{+}$) and apoptosis by both the upper right quadrant (late apoptosis/ necrosis, FITC Annexin $\mathrm{V}^{+} / \mathrm{PI}^{+}$) and lower right quadrant (early apoptosis, FITC Annexin $\mathrm{V}^{+} / \mathrm{PI}{ }^{-}$), while viable cells of each group were present in the lower left quadrant (FITC Annexin V/PI') (Fig. 6). Of these, the FITC Annexin $\mathrm{V}^{+}$cells (right quadrants) were considered as apoptotic cells whilst the FITC Annexin $\mathrm{V}^{-} / \mathrm{PI}^{+}$cells (upper left quadrant) as dead one. The mean values of the apoptotic cell rate and dead cell rate of each cell line were calculated from three independent experimental replicates of FCM assay. The LSD multiple comparison test was employed to statistically analyze the significant difference between the normal control and each treated groups for each cell line. As shown in Table I, pPeOp at any concentration as well as PVP at $120 \mu \mathrm{g} / \mathrm{ml}$ had no marked effect on MC-1 since no significant difference of either cell death or cell apoptosis can be seen between the normal and any other treated cells (both $\mathrm{P}>0.05$ ). However, treatment on MC-4 resulted in significant differences of both cell death and cell apoptosis between the normal groups and treated groups (both $\mathrm{P}<0.05$ ), of which $\mathrm{pPe} O \mathrm{p}$ treatment from 45 to $120 \mu \mathrm{g} / \mathrm{ml}$ induced significant increase of cell death in a concentration-dependent manner and that from 30 to $120 \mu \mathrm{g} / \mathrm{ml}$ also increased cell apoptosis significantly. A similar result was seen in SGC-7901 that $\mathrm{pPe} O \mathrm{p}$ was effective on increasing cell death significantly over its whole concentration range $(\mathrm{P}<0.05)$ and could also exert a 


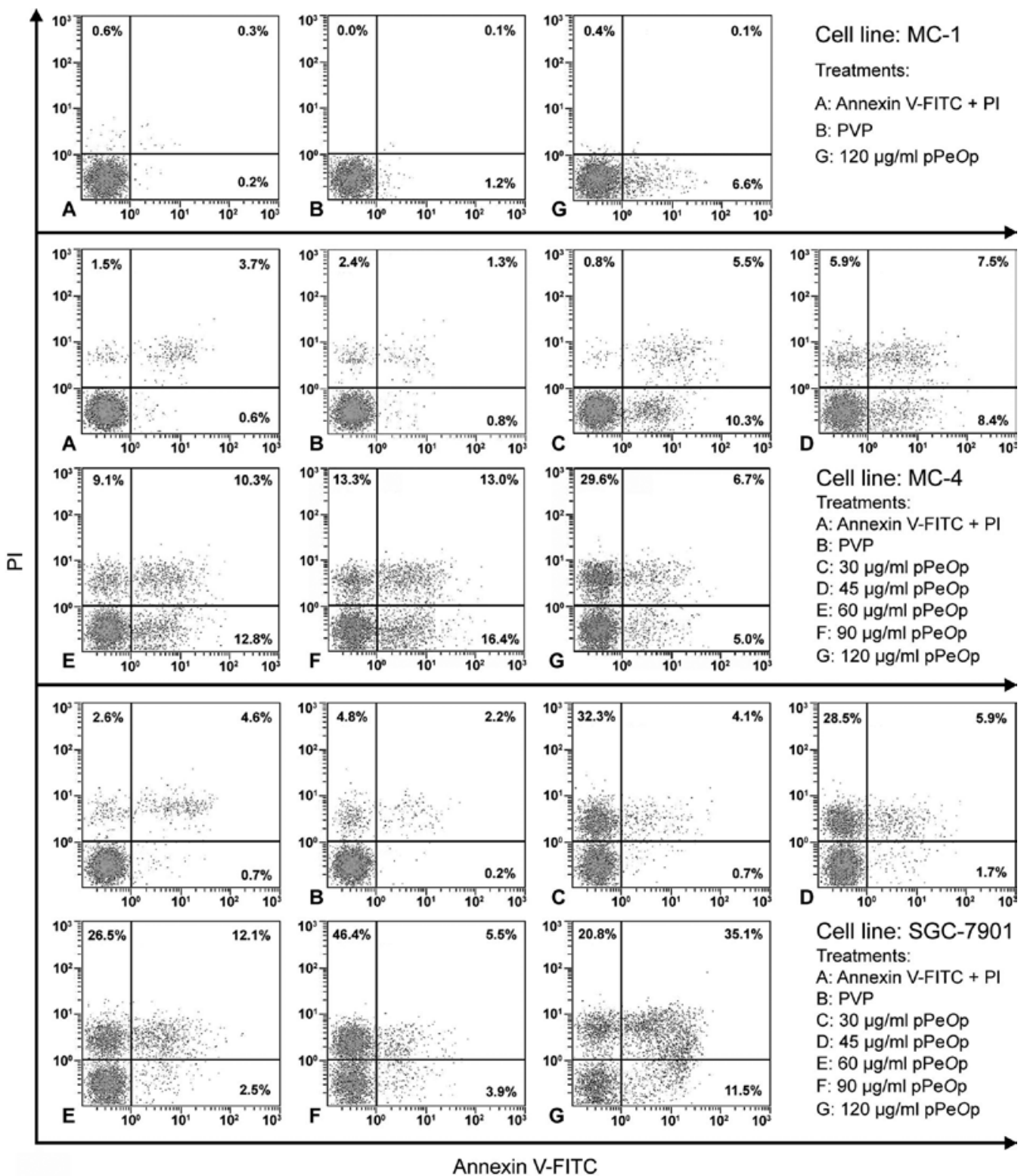

Figure 6. Cytotoxicity of pPeOp on normal cell line (MC-1) and tumor cell lines (MC-4 and SGC-7901) determined by FCM assay. (A) Normal controls; (B) PVP treated negative controls; (C-G) cells treated with $\mathrm{pPe} O \mathrm{p}$ of gradient concentrations $(30,45,60,90 \mathrm{and} 120 \mu \mathrm{g} / \mathrm{ml})$. Data shown in each quadrant represent the percentage of cells treated in each group and are representative of three independent experiments.

significant apoptosis-inducing effect at its concentration of 60 and $120 \mu \mathrm{g} / \mathrm{ml}(\mathrm{P}<0.05)$. Further, no obvious effect of PVP on the cell death or cell apoptosis could be found in MC-4 or $\mathrm{SGC}-7901$. These findings indicated that pPeOp can substantially induce cell death and cell apoptosis in the gastric tumor cell lines without any negative effect on the normal gastric cells.

\section{Discussion}

O. lapidescens regarded as both the TCM and medicinal fungus is widely used to treat diseases in clinic for thousands of years (26). Traditionally, its fruiting body, in which many bioactive ingredients such as polysaccharides and proteins are involved, is used for treatment. Those ingredients have attracted growing interest for their therapeutic effects (12-14).
However, no studies have hitherto reported on the antitumor activity of any protein of $O$. lapidescens. To date, only one protein classified as neutral metalloprotease has been found possessing anthelmintic activity (13). However, recently, our preliminary study has discovered that a crude protein extract of $O$. lapidescens fruiting body possessed inhibitory effect against tumor cell growth (14). Accordingly, in this study, we purified one protein $(\mathrm{pPe} O \mathrm{p})$ from the protein extract and performed MTT assay and FCM assay to evaluate its antitumor activity on human gastric tumor cells as well as normal gastric cells.

After a preliminary screening, PVP was chosen as an extract agent for the protein extraction, due to its favorable property of non-toxicity, high solubility and chemical stability (17). Moreover, it was reported to possess a high polyphenolaffinity which could indirectly protect protein activity from 
polyphenol-induced denaturation (19). Lee and Yun (27) have demonstrated that there are diverse fungal polyphenols in medicinal fungi such as Phellinus linteus and Inonotus xeranticus, and the polyphenols composed the yellow pigment produced in the fungal fermentation broth. In this study, we found the crude extract of $O$. lapidescens displayed yellow pigmentation, indicating that the yellow pigment composed of polyphenols may exist in this fungus. It can be deduced that, during the extraction, the polyphenol-induced denaturation may occur and the activity of fungal proteins may thereby be inhibited. Thus, applying PVP to the extraction in this study was expected to result in a counteraction of the polyphenolinduced denaturation. To our knowledge, this is the first study reporting the application of PVP for the fungal-protein extraction.

$\mathrm{pPe} O \mathrm{p}$ with molecular weight of $16 \mathrm{kDa}$ was purified from the PVP-extracted protein mixture of $O$. lapidescens by gel filtration chromatography. The chromatographic profile showed no interference among the three purified fractions G-1, G-2 and G-3 (Fig. 2), indicating that the purification was well accomplished and each peak of the fraction represented a pure protein component of $O$. lapidescens. In fact, $\mathrm{pPe} O \mathrm{p}(\mathrm{G}-2)$ as the highest-concentration component in the PVP-extracted protein mixture was reported for the first time in this study. Although its amino acid sequence has not been determined, it will not be the known protein (neutral metalloprotease) of O. lapidescens because: i) the known metalloprotease was extracted with $95 \%$ ethanol rather than PVP, indicating that $\mathrm{pPe} O \mathrm{p}$ might be denatured by polyphenols or not be extracted successfully; ii) the metalloprotease was obtained from the cultured mycelia of $O$. lapidescens strain but not from the fruiting body in which $\mathrm{pPe} O \mathrm{p}$ existed; and iii) the molecular weight of metalloprotease $(40 \mathrm{kDa})$ was much higher than that of $\mathrm{pPe} O \mathrm{p}(16 \mathrm{kDa})$. Therefore, this is the first discovery of such a protein of $O$. lapidescens, even though it has not been identified yet. However, whether it is a novel fungal protein or what amino acid sequence it has, requires further study.

Both MTT assay and FCM assay, accompanied with morphological observation, were employed in this study. The morphological changes, cell viability, cell death rate and cell apoptosis rate of the tumor cells (MC-4 and SGC-7901) and normal cells (MC-1) were assessed to determine whether $\mathrm{pPe} O \mathrm{p}$ could exert significant and specific antitumor activity. The results of both the morphological observation and MTT assay showed that $\mathrm{pPe} O \mathrm{p}$ possessed a significant inhibitory effect on gastric tumor cells in a concentration-dependent manner with an insignificant effect on normal gastric cells. With its highest concentration $(120 \mu \mathrm{g} / \mathrm{ml})$, most of the tumor cells suffered necrosis and/or apoptosis with cell shrinkage, boundary split, and nucleus fragmentation, under the light microscopy and fluorescence microscopy (Figs. 3 and 4), and the decrease of each tumor cell viability of more than $30 \%$ (38.33\% in MC-4 and 31.90\% in SGC-7901) was found by the MTT assay (Fig. 5). The FCM assay also revealed a similar result that $\mathrm{pPe} O \mathrm{p}$ could induce tumor cell death or apoptosis significantly (Table I). The statistically significant difference between the treated and untreated cells were evaluated using LSD test, in which the different lower case letters meant significant difference between each variable $(\mathrm{P}<0.05)$. However, no concentration-dependent manner of pPeOp's apoptosis-inducing effect on tumor cells was observed. It may be due to the fact that this assay cannot completely distinguish the late apoptosis and cell death in the upper right quadrant of the cell plot, neither could we distinguish the apoptotic death and non-apoptotic death in the upper left quadrant. Therefore, the cell apoptosis rate and cell death rate might not be exactly measured, resulting in the irregularity of the data. Anyway, there still existed a trend toward an increase of cell apoptosis and cell death with increased concentrations of pPe $O$ p (Table I). During all these tests, $\mathrm{MC}-1$ was employed for assessing cytotoxicity of $\mathrm{pPe} O \mathrm{p}$ on normal cells, by which the adverse effects of pPe $O \mathrm{p}$ could be somewhat evaluated. The results indicated that $\mathrm{pPe} O \mathrm{p}$ might do no significant harm to normal gastric cells from the aspects of morphology, cell viability and cell apoptosis/death rate. Nevertheless, as shown in Table I, there was an insignificant increase of MC-1 cell apoptosis after $\mathrm{pPe} O \mathrm{p}$ treatments, as compared with untreated cells $(\mathrm{P}>0.05)$, indicating that $\mathrm{pPe} O \mathrm{p}$ might trigger slight apoptosis of normal gastric cells. Whether such an adverse effect of $\mathrm{pPe} O \mathrm{p}$ is indeed present needs further evaluation and confirmation. Furthermore, according to the TCM theory, $O$. lapidescens as a TCM is attributed to the stomach meridian, indicating that this fungus can exert medicinal effect on gastric diseases $(10,11)$. That is why we have preferentially chosen gastric tumors for this study. Fortunately, the present results have supported our hypothesis that such an $O$. lapidescens protein might be effective on gastric tumors and also have supported the above TCM theory about meridian tropism to some extent.

At present, many proteins from different sources have been found to possess antitumor activity (28-32). Of these, fungal proteins are the major one, in which fungal immunomodulatory protein (FIP), ribosome-inactivating protein (RIP), lectins, and glycoproteins, are involved, due to their favorable effect against a variety of tumors (33). In this study, $\mathrm{pPe} O \mathrm{p}$, as a newly discovered antitumor protein of $O$. lapidescens, could successfully inhibit gastric tumor cell proliferation in vitro, providing a promising candidate of fungal protein for the treatment against cancer, especially gastric cancer. However, what kind of protein $\mathrm{pPeOp}$ is and whether it is effective in vivo or even in the clinic, require further exploration. The next step will be to analyze the gene sequence and amino acid structure of $\mathrm{pPe} O \mathrm{p}$, and meanwhile it will proceed to in vivo experiments.

In conclusion, based upon our preliminary study, a crude antitumor protein extract from $O$. lapidescens was found (14). In this study, we isolated and purified $\mathrm{pPe} O \mathrm{p}$ with $16-\mathrm{kDa}$ molecular weight from that extract and in vitro evaluated its antitumor activity by morphological analysis, MTT assay and FCM assay. Collectively our results obtained from the present study, we can conclude that $\mathrm{pPe} O \mathrm{p}$ possesses a significant cytotoxic effect against human gastric tumors (MC-4 and SGC 7901) in a concentration-dependent manner, with no side effect on normal gastric cells (MC-1). This is a newly discovered antitumor protein of $O$. lapidescens, owing to the first application of PVP in the fungal protein extraction as well as the first report on such a bioactive protein. Additionally, the anticancer potential of $\mathrm{pPe} O \mathrm{p}$ indicates for the first time that $O$. lapidescens may be a promising resource for new 
drug development against cancer, especially gastric cancer. Further studies are required to identify $\mathrm{pPe} O \mathrm{p}$ and evaluate its antitumor effect in vivo.

\section{Acknowledgements}

This study was financially supported by Zhejiang Provincial Natural Science Foundation of China (Y207765) and Subject of Zhejiang TCM Administration Bureau (2007YA005). The authors thank Jiangling Zhao for his help with the cell culture and Huanpeng Gu for his help with the FCM assay in this study.

\section{References}

1. Mohan H: Textbook of Pathology. Jaypee Brothers Medical Publishers Ltd., New Delhi, pp445, 2006.

2. Suzuki I, Yadomae T, Yonekubo H, Nishijima $M$ and Miyazaki T: Anti-tumor activity of an immunomodulating material extracted from a fungus, Peziza-vesiculosa. Chem Pharm Bull 30: 1066-1068, 1982.

3. Kellof GJ: Perspective on cancer chemoprevention research and drug development. Adv Cancer Res 78: 199-334, 2000.

4. Lin ZB and Zhang HN: Anti-tumor and immunoregulatory activities of Ganoderma lucidum and its possible mechanisms. Acta Pharmacol Sin 25: 1387-1395, 2004.

5. Akihisa T, Nakamura Y, Tagata M, et al: Anti-inflammatory and anti-tumor-promoting effects of triterpene acids and sterols from the fungus Ganoderma lucidum. Chem Biodivers 4: 224-231, 2007.

6. Chang HH, Hsieh KY, Yeh CH, Tu YP and Sheu F: Oral administration of an Enoki mushroom protein FVE activates innate and adaptive immunity and induces anti-tumor activity against murine hepatocellular carcinoma. Int Immunopharmacol 10 : 239-246, 2010.

7. Agaie BM and Onyeyili PA: Anthelmintic activity of the crude aqueous leaf extracts of Anogeissus leiocarpus in sheep. Afr J Biotechnol 6: 1511-1515, 2007.

8. Miyazaki T and Nishijima M: An alkalisoluble glucan of Omphalia lepidescence. Chem Pharm Bull 28: 3118-3121, 1980.

9. Dedman V: 'Native bread' Polyporus mylittae. Fungimap Newsletter 13: 6-7, 2000.

10. China Pharmacopoeia Committee: Pharmacopoeia of the People's Republic of China (the first division). China Chemical Industry Press, Beijing, pp334-335, 2010.

11. Zhu ZZ, Huang YZ, Tao JW and Li ZG: Science of Chinese Materia Medica. Publishing House of Shanghai University of Traditional Chinese Medicine, Shanghai, pp10-13, 2003.

12. Ohno N, Miura T, Saito K, Nishijima M, Miyazaki T and Yadomae T: Physicochemical characteristics and antitumor activities of a highly branched fungal $(1 \rightarrow 3)-\beta$-D-glucan, OL- 2 , isolated from Omphalia-lapidescens. Chem Pharm Bull 40: 2215-2218, 1992

13. Zhou LH, Xu QQ, Zhang YQ, Zhou ZX, Guan WJ and Li YQ: Purification, characterization and in vitro anthelmintic activity of a neutral metalloprotease from Laccocephalum mylittae. Biotechnol Bioeng 18: 122-128, 2010.
14. Chen YT, Lin MA, Cheng DQ, Shi ZJ, Zhu JL and Wu J: Effect of proteins extracted from mycelia of Omphalia lapidescens on inhibiting $\mathrm{H} 22$ liver cancer in mice and regulating immune function. Zhong Yao Cai 32: 1870-1874, 2009.

15. Reppe W: Chemie und Technik der Acetylen-Druck-Reaktionen. Verlag Chemie, Weinheim, 1951.

16. Reppe W: Neue Entwicklungen auf dem Gebiete der Chemie des Acetylens und Kohlenoxyde. Springer Verlag, Berlin, 1949.

17. PVP, an Annotated Bibliography. General Aniline \& Film Corporation, New York, 1951.

18. Hecht $\mathrm{G}$ and Weese H: Periston, ein neuer Blutflüssigkeitsersatz. Münch Med Wochenschr 90: 11-15, 1943.

19. Ma TF and Shi TJ: Properties, synthesis and application of PVP. Appl Chem Ind 31: 16-19, 2002.

20. Yi QP, Luo ZR and Zhang QL: Advance of genome DNA extraction and purification in plants. J Anhui Agri Sci 35: 7789-7791, 2007.

21. Jiang CJ, Li YY and Wang ZX: Study on the extraction conditions of $\beta$-glucosidase in fresh leaves of tea plant. J Nanjing Agri Univ 23: 93-96, 2000.

22. Smith PK, Krohn RI, Hermanson GT, et al: Measurement of protein using bicinchoninic acid. Anal Biochem 150: 76-85, 1985.

23. Schägger $H$ and von Jagow G: Tricine-sodium dodecyl sulfatepolyacrylamide gel electrophoresis for the separation of proteins in the range from 1 to $100 \mathrm{kDa}$. Anal Biochem 166: 368-379, 1987.

24. Stephano JL, Gould M and Rojas-Galicia L: Advantages of picrate fixation for staining polyproteins in polyacrylamide gels. Anal Biochem 152: 308-313, 1986.

25. Tang QY and Feng MG: DPS data processing system: experimental design, statistical analysis and data mining. Science Press, Beijing, 2007.

26. Dictionary of Traditional Chinese Medicine. Shanghai Science and Technology Press, Shanghai, 1996.

27. Lee IK and Yun BS: Peroxidase-mediated formation of the fungal polyphenol 3,14'-Bihispidinyl. J Microbiol Biotechnol 18: 107-109, 2008.

28. Lin JW, Hao LX, Xu GX, Sun F, Gao F, Zhang R and Liu LX: Molecular cloning and recombinant expression of a gene encoding a fungal immunomodulatory protein from Ganoderma lucidum in Pichia pastoris. World J Microbiol Biotechnol 25: 383-390, 2009.

29. Li MG, Chen YW, Liu ZY, Shen FB, Bian XX and Meng YF: Anti-tumor activity and immunological modification of ribosome-inactivating protein (RIP) from Momordica charantia by covalent attachment of polyethylene glycol. Acta Biochim Biophys Sin 41: 792-799, 2009.

30. Ellerby HM, Lee S, Ellerby LM, et al: An artificially designed pore-forming protein with anti-tumor effects. J Biol Chem 278: 35311-35316, 2003.

31. Arimochi H, Morita K, Nakanishi S, Kataoka K and Kuwahara T: Production of apoptosis-inducing substances from soybean protein by Clostridium butyricum: characterization of their toxic effects on human colon carcinoma cells. Cancer Lett 277: 190-198, 2009.

32. Song LY, Ren SF, Yu RM, Yan CY, Li TF and Zhao Y: Purification, characterization and in vitro anti-tumor activity of proteins from Arca subcrenata Lischke. Mar Drugs 6: 418-430, 2008.

33. Li XY, Huang M and Ning AH: Research advances in antitumor protein of mushroom. J Int Oncol 34: 576-579, 2007. 